\title{
Stakeholder perceptions of legal trade in rhinoceros horn and implications for private reserve management in the Eastern Cape, South Africa
}

\author{
Oliver Thomas Wright, Georgina Cundill and Duan Biggs
}

\begin{abstract}
The proposed legalization of international trade in rhinoceros horn is a hotly debated topic. South Africa is home to a large proportion of Africa's black Diceros bicornis and white rhinoceroses Ceratotherium simum populations. Private owners are custodians of c. $25 \%$ of the country's rhinoceroses, and the introduction of legal trade in horn harvested from live rhinoceroses may therefore have significant implications for the private conservation industry. This study explores perceptions of legal trade in rhinoceros horn, and its potential implications for reserve management, among rhinoceros owners and conservation practitioners from private game reserves in the Eastern Cape Province of South Africa. Twenty-five semi-structured interviews were conducted with key informants from 17 private game reserves (c. $37 \%$ of the total number of reserves with rhinoceroses). Whereas rhinoceros owners were mostly in favour of trade, opinion among non-owners was more nuanced. Owners expressed more interest in trading in live rhinoceroses, and stockpiled horn from natural mortalities, than in sustainably harvesting rhinoceros horn for trade. Informants therefore predicted that they would not change their practices significantly if the trade were legalized. However, most informants had little confidence that CITES would lift the trade ban. The perspectives of private reserve owners and managers should be taken into account in South African and international policy discussions relating to the legal trade in rhinoceros horn.
\end{abstract}

Keywords CITES, conservation, Eastern Cape, legal trade, rhinoceros horn, stakeholder perceptions

Supplementary material for this article can be found at https://doi.org/10.1017/So030605316000764

Oliver Thomas Wright (Corresponding author) and Georgina Cundill Department of Environmental Science, Rhodes University, Environmental Science, P.O. Box 94, Grahamstown, Eastern Cape Province, 6140, South Africa E-mail oli.tw123@gmail.com

DUAN BIGGS Environmental Futures Research Institute. Griffith University, Nathan, Queensland, Australia; ARC Centre of Excellence for Environmental Decisions, Centre for Biodiversity \& Conservation Science, University of Queensland, Brisbane, Australia; Department of Conservation Ecology and Entomology, Stellenbosch University, Matieland, South Africa; and IUCN Commission on Environmental, Economic and Social Policy/Species Survival Commission Sustainable Use and Livelihoods Specialist Group, Gland, Switzerland

Received 21 January 2016. Revision requested 12 April 2016.

Accepted 5 July 2016. First published online 12 December 2016.

\section{Introduction}

The number of rhinoceroses poached annually in South 1 Africa has increased exponentially in recent years, with a record 1,215 individuals poached in 2014, compared to 13 in 2007 (Ferreira et al., 2012; WWF, 2015). A further 1,175 rhinoceroses were poached in 2015, and rhinoceros population growth is expected to become negative if current poaching levels continue (Emslie \& Knight, 2014; DEA, 2016). This raises concern for the survival of rhinoceroses in Africa, as South Africa is home to $93 \%$ of the continent's white rhinoceros Ceratotherium simum and $41 \%$ of its black rhinoceros Diceros bicornis (Emslie \& Knight, 2014).

Increased poaching pressure can be attributed to rising demand for rhinoceros horn in Asian consumer countries such as China and Vietnam, where it is valued as a status symbol and for its perceived medicinal properties (Child, 2012; Milliken \& Shaw, 2012; Biggs et al., 2013; Ngwakwe \& Mokgalong, 2014). The supply of rhinoceros horn has been restricted by CITES (2016), which prohibits all international trade of horn. Some have argued that this has resulted in maintenance of high prices for rhinoceros horn, and facilitated the emergence of a lucrative illegal trade (Leader-Williams, 1992; Eustace, 2012; Biggs et al., 2013; Dutton et al., 2013; Duffy, 2014). Alternative efforts designed to complement the trade ban, such as militarized anti-poaching operations, dehorning of rhinoceroses, and demand reduction efforts in consumer countries, have thus far been insufficient to curb the escalating poaching problem (Lindsay \& Taylor, 2011; Martin, 2012; Biggs et al., 2013; Kagande \& Musarurwa, 2014; Di Minin et al., 2015).

Proponents of a legal trade argue that the sale of stockpiled and sustainably harvested horn from live rhinoceroses could supply the demand for horn, fund anti-poaching efforts, reduce the incentives to poach rhinoceroses and increase incentives for conservation of rhinoceroses by private landowners (Child, 2012; Biggs et al., 2013). However, uncertainties exist regarding the potential effects of legal trade on consumer demand, and the feasibility of intensive breeding programmes for supplying rhinoceros horn in the long term (Collins et al., 2013a,b). The corruption currently associated with illegal trade may persist if trade is legalized (Rademeyer, 2012). If the price of rhinoceros horn is not reduced there is also the possibility that competition from illegal traders will remain strong and continue to undermine legal trade (Collins et al., 2013a). Taking into account this uncertainty, long-term demand management strategies 


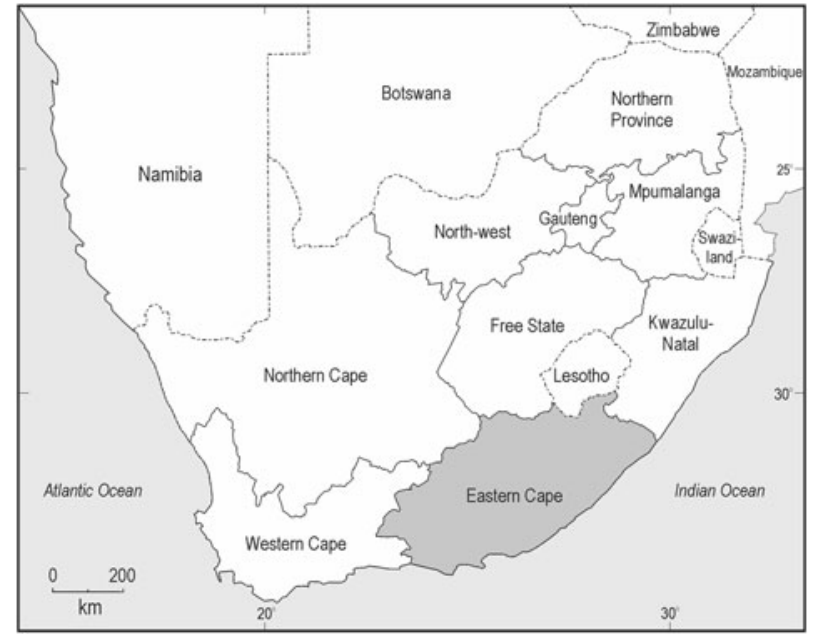

Fig. 1 The location of Eastern Cape Province, South Africa.

based on consumer education and behaviour modification may be more effective in curbing poaching than legal trade (Crookes \& Blignaut, 2015). Either way, the debate over whether or not to legalize trade in rhinoceros horn continues (Biggs et al., 2013; Collins et al., 2013a,b; Crookes \& Blignaut, 2015).

Private owners are custodians of c. $25 \%$ of South Africa's rhinoceroses. The successful implementation of legal trade in rhinoceros horn would require buy-in from, and primarily affect, these stakeholders. However, the perceptions of a potential legal trade among key stakeholders on private game reserves have not been adequately considered.

The objective of this research was to explore the perceptions of legal trade in rhinoceros horn and its potential implications for reserve management among private conservation stakeholders in the Eastern Cape Province of South Africa. In particular we explored (1) how stakeholders perceive the prospect of regulated legal trade in rhinoceros horn, and (2) the expected implications for management among private conservation stakeholders.

\section{Study area}

This study focused on private game reserves in the Eastern Cape Province of South Africa (Fig. 1). The Eastern Cape $\left(169,000 \mathrm{~km}^{2}\right)$ is situated in the south-east of the country and constitutes $13 \%$ of South Africa's total land area (Hamman \& Tuinder, 2012). The majority of reserves included in the study were located in the Cacadu district, with the exception of two reserves located in the Amatole district.

Circa $10 \%$ of the land in the Eastern Cape is under conservation of some sort, with $20 \%\left(1,540 \mathrm{~km}^{2}\right)$ of the province's conservation estate comprising private conservation areas (Sims-Castley et al., 2005; Hamman \& Tuinder, 2012). The growth of ecotourism (and hunting) as a lucrative land use has increased the number of private game reserves in the province, with large tracts of marginal pastoral land being converted for game ranching and ecotourism operations (Smith \& Wilson, 2002; Sims-Castley et al., 2005; Cumming et al., 2015).

Both white and black rhinoceroses are found on private game reserves in the Eastern Cape (Langholz \& Kerley, 2006; ECPTA, 2015). Unlike the indigenous black rhinoceros, the white rhinoceros is outside its natural range in the Eastern Cape but has been introduced on reserves with suitable grassland habitat in a bid to increase the appeal of these areas for tourists (Skead, 1987; Sims-Castley et al., 2005; Langholz \& Kerley, 2006). Of the 42 rhinoceroses poached in the Eastern Cape during 2010-2015, 15 were poached in 2014 (WESSA, 2015). Poaching in the province increased further in 2016, with a record 19 rhinoceroses having been killed by 10 October, and there is cause for concern among private conservation stakeholders that rhinoceros poaching in the Eastern Cape will continue to increase (Wilson, 2016).

\section{Methods}

An inductive approach was taken for this study as the research was aimed at building an in-depth understanding of a complex topic on which no previous empirical research had been conducted (Newing, 2010). Data were collected by means of semi-structured interviews with key informants, which comprised open-ended and closed-ended questions, yielding qualitative and quantitative data (Supplementary Material 1; Bernard, 2002; Newing, 2010). The purpose of the key informant interviews was to capture a representative reflection of the perceptions of key stakeholders involved in private game reserve management in the Eastern Cape regarding the potential legalization of trade in rhinoceros horn and associated implications for reserve management.

Data collection took place during June-October 2015. Key informants were contacted initially by email and telephone to arrange interviews, and contact was made with additional informants by means of snowball sampling through referrals. Interviews were conducted with 25 informants from 17 private game reserves. Increasing the sample size proved to be challenging because of security concerns; many potential informants were reluctant to be interviewed for fear that poachers would gain access to information they shared about rhinoceroses. The sample of 17 reserves comprises c. $37 \%$ of the 46 reserves with rhinoceroses in the Eastern Cape.

Ten of the 25 informants were rhinoceros owners. The other 15 , referred to broadly as managers, included fulltime conservation management practitioners who specialized in a variety of activities, such as anti-poaching, security and crime intelligence, game capture, veterinary medicine, 
ecology, and general game ranch management. Most of the informants worked full-time on reserves with rhinoceroses and were actively involved in the day-to-day management of these reserves, with the exception of two owners who did not live and work permanently on the reserves where their rhinoceroses were kept but still had a strong philanthropic interest in rhinoceros conservation. Two of the reserves were used exclusively for rhinoceros breeding, one was primarily a hunting reserve, and one offered both hunting and photographic safaris. The other 13 reserves were primarily ecotourism operations that supplemented their income from ecotourism by selling excess game to other reserves. With the exception of the two rhinoceros breeding operations, all the reserves comprised extensive natural areas, where rhinoceroses could roam freely among other species.

Interviews were guided by a set of broad key questions while also giving the informant the freedom to raise issues they felt were relevant (Newing, 2010). We used a five-point Likert scale for closed-ended questions. Interviews were recorded, with the permission of informants (and later transcribed), and recordings were supported by hand-written notes. Given the contentious nature of rhinoceros poaching, informants were assured anonymity, and the names and locations of farms have not been disclosed (Supplementary Material 2). Key informants were free to decline to discuss topics or answer questions. Care was taken not to lead informants with suggestive questions or the personal opinions of the interviewer.

Qualitative data were transcribed and coded to identify key themes, patterns and relationships. Where suitable, qualitative data were converted to quantitative data by assigning a code to a recurring theme, counting the number of times the theme occurred and interpreting the numerical data from the count using descriptive statistics (Newing, 2010). Quantitative data and direct quotes from informants are used as evidence to support claims and illustrate nuances (Taylor-Powell \& Renner, 2003; Thomas, 2006; Newing, 2010).

\section{Results}

\section{Perceptions of poaching}

All of the informants interviewed acknowledged that rhinoceros poaching was a problem in the Eastern Cape (Table 1). Nineteen of the 25 informants believed that rhinoceros poaching posed a threat to conservation in general in the Eastern Cape, whereas the remainder suggested that the effects of poaching were limited to rhinoceros species alone (Table 1). Seventeen informants perceived poaching as a threat to their personal safety and 11 perceived it as a threat to their livelihood (Table 1).
When discussing safety concerns, informants raised various issues, including the fear of encountering armed poachers, the dangers of storing rhinoceros horn on the property, and fears for the safety of their families or staff. Informants who perceived poaching as a threat to their livelihoods were concerned about the diminishing returns they were getting for selling live rhinoceroses, or pointed out the importance of rhinoceroses for attracting tourists, citing fears that reduced occupancy rates would lead to job losses if rhinoceroses were removed from the reserve.

Thirteen informants suggested that rhinoceros poaching was resulting in a decreased interest in rhinoceros conservation (Table 1), with some indicating that they had considered or were considering removing rhinoceroses from their property. Twelve informants expressed concern about the costs associated with protecting the rhinoceroses on their reserves, as security costs increase with the threat of poaching (Table 1). Eight informants suggested rhinoceros poaching in the Eastern Cape was increasing, with some $(n=5)$ suggesting that poaching pressure was shifting from the north of South Africa to the Eastern Cape as militarized anti-poaching efforts intensified in the Kruger National Park and surrounds (Table 1). Eight informants expressed dissatisfaction with the level of law enforcement provided by the state in the province. Five suggested that poaching in the Eastern Cape was more sophisticated than elsewhere in South Africa, referring to the professional manner in which rhinoceroses had been poached in the province, and the use of dart guns by poachers (Table 1).

\section{Perceptions of legal trade in rhinoceros horn}

Level of agreement/disagreement that trade should be legalized More than half of the respondents either agreed or strongly agreed that regulated trade in sustainably harvested rhinoceros horn should be legalized (Fig. 2). Rhinoceros owners were in favour of legal trade, whereas opinion among managers was more balanced (Fig. 2).

Positive perceptions of legal trade Most informants $(\mathrm{n}=21)$ highlighted the additional income from trading in rhinoceros horn as a positive outcome of legalizing trade (Table 2). Sixteen informants suggested that legal trade would result in rhinoceros species being better protected (Table 2). Some informants explained how money from trade in rhinoceros horn could directly finance the protection of rhinoceroses by giving reserves the means to improve their anti-poaching presence or invest in new technology such as aerial drones or fence-line cameras. Others felt legalization would lead to an increase in the value of live rhinoceroses and create more of an incentive for owners to invest money in their protection (Table 2). Several informants referred to the thriving trade in rare 
TABLE 1 Summary of informants' perceptions of rhinoceros poaching.

\begin{tabular}{|c|c|c|}
\hline Perception & $\begin{array}{l}\text { No. of informants } \\
(\mathrm{N}=25)\end{array}$ & Sample statement by key informant \\
\hline $\begin{array}{l}\text { Threat to conservation in the Eastern } \\
\text { Cape }\end{array}$ & $19(76 \%)$ & $\begin{array}{l}\text { I think rhino is a sort of charismatic species \& it's a huge drawcard in terms } \\
\text { of ecotourism, so we know if we didn't have rhino on the property there's } \\
\text { less of a chance of making bookings because of it not being present, sadly. } \\
\text { [Rhinoceros owner, Reserve 3] }\end{array}$ \\
\hline Threat to safety & $17(68 \%)$ & $\begin{array}{l}\text { If these people come onto your property, if my guards spot someone then } \\
\text { they're going to phone me, \& I have to go out there, it's actually a threat to } \\
\text { your life, it's a threat to my family's life. [Rhinoceros owner, Reserve 10] }\end{array}$ \\
\hline $\begin{array}{l}\text { Decreasing interest in rhinoceros } \\
\text { conservation }\end{array}$ & $13(52 \%)$ & $\begin{array}{l}\text { At this stage we're still keeping rhino, but it's a big question, how do you } \\
\text { justify keeping them in today's world? [General manager, Reserve 3] }\end{array}$ \\
\hline $\begin{array}{l}\text { Difficult to cover costs of rhinoceros } \\
\text { protection }\end{array}$ & $12(48 \%)$ & $\begin{array}{l}\text { These animals just cost. They cost in security, they cost in diesel, they cost } \\
\text { in food, they cost in fencing, \& there's no return. [Farm manager, Farm 17] }\end{array}$ \\
\hline Threat to livelihood & $11(44 \%)$ & $\begin{array}{l}\text { If the game reserve shuts down I'm out of the job you know, so if you're } \\
\text { heavily targeted \& got no rhino left, it would definitely be a threat to my } \\
\text { livelihood. [Ecologist \& wildlife manager, Reserve 1] }\end{array}$ \\
\hline Inadequate law enforcement & $8(32 \%)$ & $\begin{array}{l}\text { Your police, your hawks, they should be doing the work. What we've ended } \\
\text { up doing is, because of their inability or lack of motivation, as private rhino } \\
\text { owners we've found that we have to do that work, we have to instruct them, } \\
\text { push them, beg them, it's ridiculous, absolutely ridiculous. [Rhinoceros } \\
\text { owner, Reserve 1] }\end{array}$ \\
\hline $\begin{array}{l}\text { Poaching is on the increase in the } \\
\text { Eastern Cape }\end{array}$ & $8(32 \%)$ & $\begin{array}{l}\text { It's increasing by the year or by the month almost. Last year was the worst } \\
\text { year ever, we had } 15 \text {. Now } 15 \text { doesn't sound a lot, but we only have about } \\
2 \% \text { of the national population in the Eastern Cape. So in comparison we're } \\
\text { actually being hit just as hard as any other province. [Security consultant } \& \\
\text { wildlife crime specialist, Reserve 11] }\end{array}$ \\
\hline $\begin{array}{l}\text { Poaching pressure is beginning to shift } \\
\text { from the north }\end{array}$ & $5(20 \%)$ & $\begin{array}{l}\text { The more successful they are with their anti-poaching in the Kruger } \\
\text { National Park \& Limpopo \& Mpumalanga, the more it will move down } \\
\text { here. [Rhinoceros owner, Reserve 9] }\end{array}$ \\
\hline $\begin{array}{l}\text { Rhinoceros poaching is more sophis- } \\
\text { ticated in the Eastern Cape }\end{array}$ & $5(20 \%)$ & $\begin{array}{l}\text { All those guys (in the Kruger National Park), they're using old 303s \& } \\
\text { bullets to shoot them. Where with ours it is more a sophisticated syndicate } \\
\text { of poachers that have access to M99 \& dart guns, \& people who can operate } \\
\text { them... [Rhinoceros owner, Reserve 8] }\end{array}$ \\
\hline
\end{tabular}

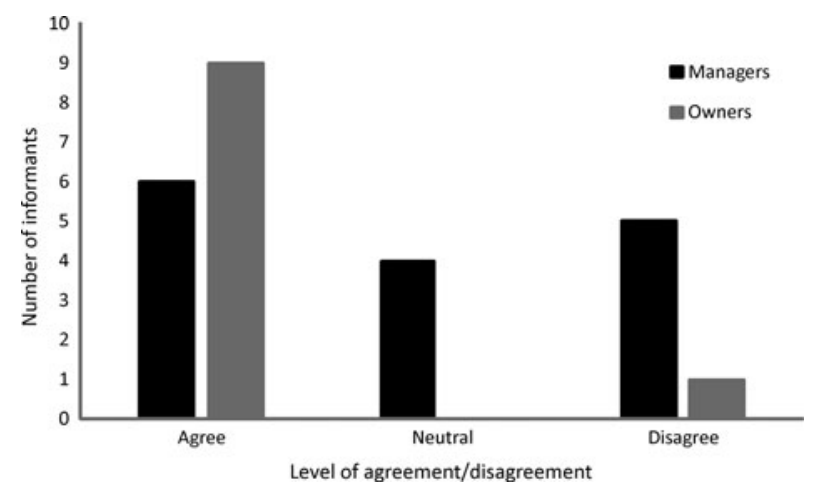

FIG. 2 Level of agreement/disagreement among rhinoceros owners $(n=10)$ and managers $(n=15)$ that regulated trade in sustainably harvested rhinoceros horn should be legalized.

game species in South Africa, citing successes in the trade in species such as buffalo Syncerus caffer, bontebok Damaliscus pygargus dorcas, sable Hippotragus niger and roan antelope Hippotragus equinus as examples of how placing value on live rhinoceroses (and not just horn as a by-product) may ensure their protection. Fourteen informants suggested that legal trade in rhinoceros horn would help to expand the natural ranges of rhinoceros species, with some highlighting the broader benefits for biodiversity conservation and the conservation industry that would come from increasing South Africa's conservation estate to accommodate more rhinoceroses (Table 2).

Negative perceptions of legal trade Corruption $(\mathrm{n}=19)$ and poor enforcement of regulations $(n=17)$ were major concerns among most informants (Table 3). Many informants questioned the capacity of the South African government to regulate the sale of rhinoceros horn, with some suggesting that trade would only work if regulation was carried out independently of the government by a private entity. Ten informants raised the concern that illegal trade would continue to operate parallel to legal trade in the absence of adequate regulation (Table 3 ). Twelve informants were concerned about the uncertainty of demand for rhinoceros horn in consumer countries, with 
TABLE 2 Summary of informants' positive perceptions of legal trade in rhinoceros horn.

\begin{tabular}{|c|c|c|}
\hline Perception & $\begin{array}{l}\text { No. of informants } \\
(\mathrm{N}=25)\end{array}$ & Sample statements by key informants \\
\hline Extra income from trade & $21(84 \%)$ & $\begin{array}{l}\text { We're going to get some money back for conservation. Unfortunately conservation } \\
\text { costs money. You need to get something back. [Rhinoceros owner \& breeder, } \\
\text { Reserve 10] }\end{array}$ \\
\hline $\begin{array}{l}\text { Better protection for } \\
\text { rhinoceros }\end{array}$ & $16(64 \%)$ & $\begin{array}{l}\text { I think if the trade was legalized it would create direct financing into protecting the } \\
\text { remaining rhino, protecting the rhino breeding crèches. [Rhinoceros owner, } \\
\text { Reserve 3] }\end{array}$ \\
\hline $\begin{array}{l}\text { Increased value of live } \\
\text { rhinoceros }\end{array}$ & $15(60 \%)$ & $\begin{array}{l}\text { If you allow legal trade in rhino horn, rhino will become the most expensive species in } \\
\text { the country \& therefore it will become the most looked after species, or cared for } \\
\text { species in the country. [Rhinoceros owner, Reserve 6] }\end{array}$ \\
\hline Expand rhinoceros range & $14(56 \%)$ & $\begin{array}{l}\text { One thing that I'm confident is that if legal trade will happen, the value of rhino would } \\
\text { increase. So more wildlife landowners would have rhino. And that is quite important } \\
\text { for the sake of available habitat to rhino. [Wildlife manager \& veterinarian, Reserve 11] }\end{array}$ \\
\hline $\begin{array}{l}\text { Conservation industry } \\
\text { will grow }\end{array}$ & $12(48 \%)$ & $\begin{array}{l}\text { I just think the whole industry will grow. If we look at other species how they've grown, } \\
\text { all the other species how they're benefitting from this industry. [Rhinoceros owner, } \\
\text { Reserve 1] }\end{array}$ \\
\hline $\begin{array}{l}\text { Rhinoceros numbers will } \\
\text { increase }\end{array}$ & $10(40 \%)$ & $\begin{array}{l}\text { Legalizing the trade, if it's done right, will help increase the numbers definitely. } \\
\text { [Wildlife manager, Reserve 14] }\end{array}$ \\
\hline $\begin{array}{l}\text { Will reduce incentive to } \\
\text { poach }\end{array}$ & $5(20 \%)$ & $\begin{array}{l}\text { If it's legalized I would imagine the price is going to come down, so there should be } \\
\text { fewer poachers prepared to actually put their lives on the line. [Rhinoceros owner \& } \\
\text { breeder, Reserve 10] }\end{array}$ \\
\hline
\end{tabular}

TABLE 3 Summary of informants' negative perceptions of legal trade in rhinoceros horn.

\begin{tabular}{|c|c|c|}
\hline Perceptions & $\begin{array}{l}\text { No. of informants } \\
(\mathrm{N}=25)\end{array}$ & Sample statements by key informants \\
\hline Corruption & $19(76 \%)$ & $\begin{array}{l}\text { I think that the only big bearing issue is corruption, so that if we knew for a fact } \\
\text { that that was in check then this would be a no-brainer, you know 'let's do it'. } \\
\text { But that's where it all falls apart. [Rhinoceros owner, Reserve 1] }\end{array}$ \\
\hline Regulation/control & $17(68 \%)$ & $\begin{array}{l}\text { If it's not controlled \& not permitted properly you're always going to have } \\
\text { greedy people \& you don't want the rhinos to suffer at the end of the day. } \\
\text { [Rhinoceros owner, Farm 4] } \\
\text { I strongly doubt that the South African government has the capacity to } \\
\text { properly regulate the sale. [Security consultant \& wildlife crime specialist, } \\
\text { Reserve 11] }\end{array}$ \\
\hline Uncertain demand & $12(48 \%)$ & $\begin{array}{l}\text { I think the real concerns lie with what happens if you do feed the beast? You } \\
\text { know, is the beast going to grow \& how big is that beast? [Rhinoceros owner, } \\
\text { Reserve 3] } \\
\text { There's just too many unknowns \& uncertainties, we don't actually know what } \\
\text { the market is. [Rhinoceros owner, Reserve 9] }\end{array}$ \\
\hline $\begin{array}{l}\text { Continuation of parallel illegal } \\
\text { trade }\end{array}$ & $10(40 \%)$ & $\begin{array}{l}\text { If it were to be approved, I don't think the syndicates would stop working. } \\
\text { [General manager, Reserve 1] }\end{array}$ \\
\hline $\begin{array}{l}\text { Personal/tourist perceptions of } \\
\text { dehorned rhinoceros }\end{array}$ & $10(40 \%)$ & $\begin{array}{l}\text { I don't want to go \& cut rhino horn off our rhinos, imagine our guests coming } \\
\text { here \& seeing rhinos in the wild \& they don't have horns or they have half their } \\
\text { horns chopped off because we need to pay for a new tractor? [Rhinoceros } \\
\text { owner, Reserve 6] }\end{array}$ \\
\hline Intensive farming/domestication & $8(32 \%)$ & $\begin{array}{l}\text { I think you'll end up with all these farms popping up with rhino in small pens } \\
\& \text { in paddocks \& they're just being farmed for their horn which isn't ideal from } \\
\text { a conservation point of view. [Ecologist \& wildlife manager, Reserve 1] }\end{array}$ \\
\hline $\begin{array}{l}\text { Trade will undermine demand } \\
\text { reduction efforts }\end{array}$ & $5(20 \%)$ & $\begin{array}{l}\text { By legalizing the trade you're basically saying it's ok to use rhino horn, \& we're } \\
\text { trying to change the whole mind-set of the Asians, the Vietnamese people not } \\
\text { to use rhino horn because it doesn't do what they say it does. [Wildlife man- } \\
\text { ager, Reserve 13] }\end{array}$ \\
\hline
\end{tabular}


some expressing fears that legalizing trade would exacerbate demand (Table 3). Five informants were concerned that legalizing trade would undermine demand reduction efforts in consumer countries by encouraging consumption of rhinoceros horn. Ten informants raised concerns about perceptions of dehorned rhinoceroses, either because they personally did not like the idea of rhinoceroses without horns or they were concerned about tourists wanting to see intact rather than dehorned rhinoceroses. Eight informants were concerned about rhinoceroses being farmed intensively for their horns and becoming domesticated (Table 3).

Implications of legal trade in rhinoceros horn for reserve management Rhinoceros owners were more relevant informants in this case as they had the power to decide whether or not their reserves would participate in the rhinoceros horn trade. Managers' opinions about how their reserves would participate were more speculative, and in cases where both owner and manager from the same reserve were interviewed $(n=5)$ the manager's opinion of trade participation differed from that of the owner in every case.

The term dry horn is used to describe stockpiled rhinoceros horn that has not been harvested for the purpose of trade. This includes horn that has broken off accidentally (e.g. following a fight or when a rhinoceros has been confined to a boma or trailer during transport), horn from rhinoceroses that have died of natural causes, and horn that has been removed in an attempt to reduce the risk of poaching. The majority of informants predicted they would trade in dry horn if trade were legalized (Fig. 3).

The term green horn is used for horn that has been harvested sustainably from live rhinoceroses for the purpose of trading. Several informants suggested they would harvest and sell green horn from their reserve if trade were legalized (Fig. 3). However, most informants suggested that they would take a conservative approach to harvesting horn, with the exception of the manager of a breeding operation that had been set up for the purpose of harvesting horn in anticipation of trade being legalized (Fig. 3). Suggested conservative approaches to harvesting horn included harvesting only from excess bulls that would otherwise be sold to hunting farms, removing and selling horns only from aggressive bulls that had injured other animals, and harvesting only a small portion of horn from each rhinoceros in a herd.

Seven owners said that they would trade more in live rhinoceros if trade were legalized, and most owners were more enthusiastic about the live rhinoceros trade than trade in the horn itself (Fig. 3). Informants provided various reasons for their interest in trading more in live rhinoceroses, including the expectation that live rhinoceroses would cease to become a liability (if legalized rhinoceros horn trade decreased poaching) and would thus become more valuable, as well as the feeling among some rhinoceros owners that they would have more peace of mind regarding the future welfare of rhinoceroses they sold, as they would be less likely to be used for trophy hunts:

I wouldn't have a problem selling a live rhino to someone who is going to harvest its horn if I know the animal is going to stay alive. [Rhinoceros owner, Reserve 10]

Overall, most informants anticipated their reserves would not be much involved in the legal trade in rhinoceros horn, and for the most part their day-to-day management activities would not change. None of the informants predicted any large-scale changes to reserve management. Some predicted minor changes, such as security upgrades, increasing the size of their rhinoceros herd or being able to do more as a result of increased funding, but the general response among informants was that business would continue as usual on their reserves, as illustrated by the following examples of typical statements regarding the potential implications of legal trade in rhinoceros horn for reserve management:

I don't think there would be challenges. I suppose it would be like when we dehorn now. [General manager, Reserve 17]

It shouldn't have a big effect; we're going to be doing the same thing whether we dehorn or not. [Rhinoceros owner, Reserve 9]

Perspectives on CITES At the time of data collection the South African government was still exploring the possibility of proposing the legalization of international rhinoceros horn trade. Twenty-two of 25 informants suggested the trade ban would not be lifted. In explaining their lack of faith that legal trade could become a reality in 2016, informants referred to negative public opinion regarding legal trade, and a lack of understanding of the issue of rhinoceros poaching among the general public. Moreover, there was reference to the strong financial influence on CITES by 'anti-trade' NGOs, and the 'flawed' voting system at the 17th meeting of the Conference of the Parties to CITES (CoP17), where, of 181 member countries, South Africa had only one vote despite being the main custodian of wild rhinoceroses. Typical comments by informants regarding CITES CoP17 included the following:

There's probably a good chance that it won't be approved, just because of the general public who are very out of touch with reality. [Rhinoceros owner, Reserve 1]

Personally I don't think it will be legalized because of all the NGOs throughout the world. They've got a huge budget. [Rhinoceros owner and breeder, Reserve 10]

The bulk of all rhino in the world is in South Africa, and South Africa have got one vote of all the members at CoP17, so how could all those countries that have got no rhino decide how we should manage our population? So it's an absolutely ridiculous situation that we're in. [Wildlife manager and veterinarian, Reserve 11]

In the months following data collection a decision was made by the South African government not to issue a proposal at $\mathrm{CoP}_{17}$, and a last-minute trade proposal by Swaziland was rejected. 


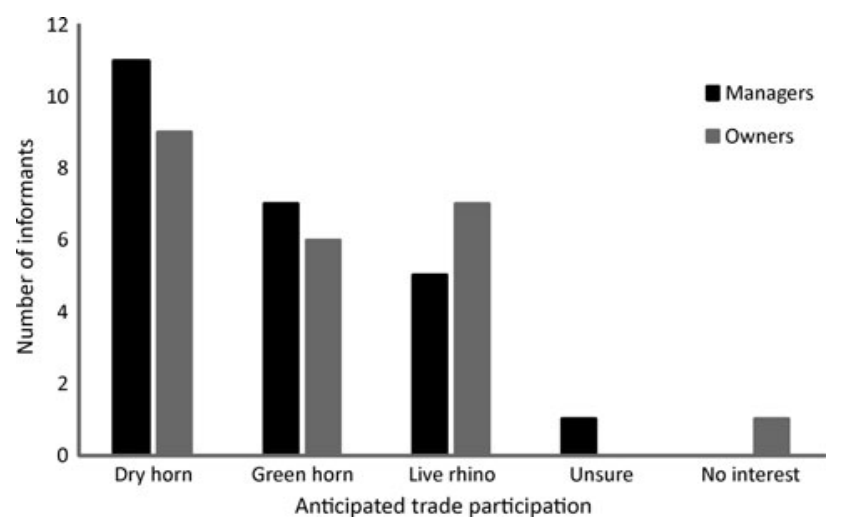

FIG. 3 Anticipated participation in legal trade by rhinoceros owners $(n=10)$ and managers $(n=15)$.

\section{Discussion}

The aim of this study was to explore the perceptions of legal trade in rhinoceros horn, and its potential management implications, among stakeholders in the private conservation industry in the Eastern Cape of South Africa. Despite harbouring several concerns regarding the viability of legal trade, many respondents perceived legal trade as a positive and useful strategy for rhinoceros conservation. In particular, respondents who supported lifting of the trade ban highlighted that legalization of trade would bring much-needed revenue for rhinoceros protection and would help to reduce poaching pressure. This suggests that legal trade in rhinoceros horn would have the support of private conservation industry stakeholders, although disparities exist between owners and managers of rhinoceroses, and several informants had a negative view of legal trade. Manager buyin in particular could be more challenging to secure in the event that trade was legalized. Most informants predicted there would be few changes to reserve management if trade were legalized, which suggests concerns that many farmers would convert to intensive farming of domesticated rhinoceroses may not reflect reality.

The threat of corruption and the question of whether legal trade could be regulated effectively were key concerns among most informants. These concerns are not unfounded. Conservation is vulnerable to corruption, especially when dealing with valuable commodities such as rhinoceros horn (Bennett, 2015; Smith et al., 2015). Corruption among government officials who manage natural resources is not uncommon, especially in developing countries such as South Africa (Smith et al., 2003; Laurance, 2004). There is also a considerable degree of regulatory uncertainty in the private wildlife sector in South Africa because of the fragmented nature of state authority and a lack of legislation supporting a clear regulatory framework for the game farming industry (Kamuti, 2014). Despite widespread concerns among respondents, however, many still maintained that trade should be legalized. Corruption is a key concern but the risk could be curtailed by means of a well thought out trade mechanism, such as a central selling organization as suggested by Biggs et al. (2013). Regardless of whether trade is legal or not, corruption in conservation is a critical issue and requires careful management when dealing with trade in wildlife products (Smith et al., 2015).

Conflict exists between various factions of conservation management worldwide, and Africa is no exception. Whereas it is common for the state and the private sector to advocate for the commoditization of nature, conservation activists frequently view nature to be an inalienable good (Snijders, 2014). Our informants highlighted such conflicts between NGOs and private conservation stakeholders by suggesting that CITES was under the control of anti-legal trade lobbyists associated with international conservation NGOs, who respondents felt were likely to influence voting on legalization at the CoP17. The relationship between members of the private wildlife industry in South Africa and conservation NGOs is generally hostile, with industry stakeholders viewing NGOs as inhibiting the potential for conservation through 'green capitalism', and NGOs viewing industry stakeholders as profiting from activities that have negative outcomes for the conservation and well-being of species (Snijders, 2014). The successful implementation of legal trade may rely on cooperation between conservation NGOs and private stakeholders, which would require disagreements over the use of wildlife to be negotiated. The conflict between conservation NGOs and rhinoceros owners may be seen as a conflict of interests between the urban elite, who contribute significant funds to conservation NGOs, and rhinoceros owners, who bear the costs of protection and management. Non-market strategies put forward by NGOs to combat poaching do not fit in with the pragmatic, utilitarian approach to conservation preferred by private custodians of rhinoceroses. A potential solution in this case may be to establish more dialogue between stakeholders who have differing views on how best to combat rhinoceros poaching, and promote compromise between supporters and detractors of legal trade; for example, conservative harvesting methods could be employed to combat poaching in the short term, alongside continued efforts to reduce consumer demand in the long term. This could be seen as a more realistic solution to the poaching crisis, given the time it will take for consumer education campaigns to take effect and the rapid rate at which rhinoceros numbers are plummeting towards extinction.

Our findings suggest there is strong support for legal trade in rhinoceros horn among rhinoceros owners specifically. This was expected, as according to a national survey by the Private Rhino Owners Association $97 \%$ of rhinoceros owners in South Africa support the lifting of the trade ban (Duffy et al., 2013). This is probably because rhinoceros owners stand to gain the most from trading in rhinoceros 
horn and live rhinoceroses if trade is legalized, and lose the most from poaching. In many cases the overall business viability of reserves with rhinoceroses is being threatened by the high costs of poaching. A concern among detractors of legal trade is that stakeholders in the private conservation industry will put commercial interests ahead of conservation goals when given the opportunity to utilize the value of their rhinoceroses. However, many landowners with rhinoceroses may be lifestyle entrepreneurs, who are interested in the lifestyle facilitated by the ownership of wildlife and private conservation land. This is reflected in the perceptions of participants in this study, and research has shown similar motivations among nature-based tourism operators in Australia (Biggs et al., 2012).

Informants mostly predicted that their participation in legal trade would be minimal, suggesting negligible implications for the way private game reserves in the Eastern Cape are managed. Rhinoceros owners expressed more interest in trading live rhinoceroses and stockpiled horn than in sustainably harvesting rhinoceros horn for trade, and those who expressed interest in harvesting rhinoceros horn did not foresee significant changes to management. Despite this view, however, new rhinoceros ranches may emerge in the province to supply the legal horn trade, and reserves that already have rhinoceroses may increase their holding. Potential management implications should therefore still be considered.

If trade were legalized, management costs could increase initially, as management strategies would need to be adjusted to address new challenges associated with breeding programmes, rhinoceros protection and the harvesting of horn (Collins et al., 2013a; Di Minin et al., 2015). Managers may have to address animal welfare issues regarding trade in live rhinoceroses, legal implications surrounding trade, and possible trade-offs between profit and conservation (Ferreira et al., 2014). Management objectives tailored to high-priority species could have a negative impact on the persistence of other species, and it is important to ensure that management strategies tailored towards rhinoceroses consider the welfare of other species in protected areas (Le Saout et al., 2013).

Captive breeding of rhinoceroses to supply horn for legal trade could require large amounts of land and costly protection measures, and may only be feasible for the white rhinoceros, as the black rhinoceros is less suited to intensive breeding (Collins et al., 2013a). There is a history of domestic herbivore-driven land degradation and biodiversity loss associated with overstocking in South Africa, and this may become a problem with rhinoceroses if they are farmed intensively (Cousins et al., 2008; Rutherford et al., 2014). Extralimital white rhinoceroses have been favoured over the indigenous black rhinoceros by reserves in the Eastern Cape because of their more favourable temperament, and the stocking of large numbers of white rhinoceroses by several reserves has raised concerns regarding possible adverse effects on the structure and function of local ecosystems (Castley et al., 2001; Sims-Castley et al., 2005; Langholz \& Kerley, 2006; Kerley et al., 2008; Maciejewski \& Kerley, 2014). Intensive farming of the white rhinoceros may therefore be less viable in the Eastern Cape.

The impact of trade policy on land use is uncertain. Legalization of trade in rhinoceros horn may catalyse the expansion of private protected areas in South Africa and thus help to disperse rhinoceros populations into areas that historically formed part of their natural range. However, it is important that potential management policies and trade mechanisms are focused on ensuring that rhinoceros species are conserved in natural areas and not just farmed intensively on ranches. As highlighted by participants in this study, rhinoceros poaching and its associated risks and costs are threatening the viability of conservation as a land use for private land owners. Future policy decisions regarding rhinoceros management may therefore influence the expansion or reduction of private protected areas in South Africa, and may have implications for the persistence of other species that share this land with populations of the white and black rhinoceros. Therefore, we argue that rhinoceros poaching in Africa should not be treated as a two-species issue, and these broader implications should be taken into account when developing and implementing future rhinoceros management policy.

More conservative methods of harvesting horn, such as shaving a small portion of horn from free-ranging wild rhinoceros, could be explored as alternatives to intensive ranching and full dehorning. The recent lifting of a moratorium on domestic trade in rhinoceros horn, on 20 May 2016, may open up a variety of opportunities for the utilization of privately owned rhinoceroses and rhinoceros horn, including a potential futures market for rhinoceros horn, based on the assumption that international trade will one day become legal; traditional Chinese medicine tourism, where consumers travel to South Africa to use rhinoceros horn; veterinary tourism associated with the darting of rhinoceroses and harvesting of small portions of horn; and trophy hunting and 'green hunts' where rhinoceroses are darted and a trophy is taken in the form of a photograph. Income from trophy hunting provided an important financial incentive for private landholders to conserve rhinoceros species prior to the implementation of the moratorium.

Incentives for private investment in biodiversity conservation are limited, and private landowners have shown reluctance to participate in conservation strategies that are not beneficial to them (Clough, 2000). Private landowners have played a key role in past successes in rhinoceros conservation in South Africa but if poaching continues to undermine the financial viability of stocking rhinoceroses on private land there is a danger that many landowners will choose to cease stocking the species (Smith et al., 
2013). Under the trade ban, incentives for private investment in rhinoceros conservation have decreased as a result of the increased security measures necessary to protect rhinoceroses, reductions in live sales, and tighter restrictions on trophy hunting (Duffy et al., 2013). Institutions such as CITES that enforce the ban on rhinoceros horn trade provide little help to private game ranchers in protecting themselves and their rhinoceroses from poachers, and the private landholders incur the costs of poaching whilst criminals reap the benefits (Child, 2012; Pernetta, 2014; Lee \& Du Preez, 2015). Reduced investment in rhinoceroses by private landowners could serve to decrease the range of rhinoceros species in South Africa as more landowners choose to sell off their rhinoceroses and less private land is used for conservation (Child, 2012; Duffy et al., 2013).

This explorative study has provided insights from the conservation stakeholders that are among those most directly affected by CITES policies on rhinoceros horn. We have highlighted the importance of engaging with owners and managers, who are not only on the front line of the poaching crisis but who will also find themselves on the front line of implementing any future policy changes. As such, these are core stakeholders whose views and experiences must be taken seriously in multinational decision making regarding trade in rhinoceros horn.

Currently CITES does not allow for private custodians of rhinoceroses to have any real influence on policy decisions regarding trade in rhinoceros horn, despite the profound impact that trade restrictions have on their conservation enterprises. It is important to note that the rhinoceros poaching crisis is a time-sensitive issue. Conflict between conservation authorities and practitioners in South Africa regarding the best course of action in the fight against rhinoceros poaching is taking up precious time that could otherwise be spent developing workable solutions that address the concerns of both parties and are in the interest of rhinoceros conservation.

Thus far, the South African government has not outlined a clear way forward for rhinoceros conservation, instead opting to continue along a management trajectory that some argue has proven insufficient to address the poaching issue. The lack of a clear vision for future South African rhinoceros conservation policy needs to be addressed urgently, and the needs of local rhinoceros custodians should be considered in formulating this vision. Clarity is required regarding the government's core conservation goal for rhinoceros species; i.e. whether poaching should be regarded as an emergency issue exclusive to rhinoceros species or whether broader issues of poverty alleviation, land use and the conservation of other species should be taken into account when considering options for rhinoceros management. The question of how rhinoceros conservation and protection will be funded is also important, and whether to continue relying on state, NGO and donor funding or to create opportunities for private stakeholders to generate funds from the utilization of live rhinoceroses and their horn.

The small sample size was a limitation to this research project, and is associated with the reluctance of stakeholders to share information regarding rhinoceroses because of fears that leaked information will lead to their reserves being targeted by poachers. Nonetheless, the study group represents private rhinoceros custodians as important stakeholders in rhinoceros conservation. It is hoped that this study will pave the way for future research that considers the perceptions of stakeholders across South Africa, and that the scope of future studies will be broadened to incorporate other key stakeholders, such as those who would be responsible for regulating a potential legal trade.

Finally, regardless of whether or not trade is legalized it is clear that action is needed to combat the growing problem of rhinoceros poaching, and that this action must be multifaceted. Policies could include the promotion of more effective law enforcement and incentives for local people to protect rhinoceroses, as well as demand reduction strategies such as legal trade and/or consumer education (Ripple et al., 2015). In the development of these policies it is critical that the perceptions of the people who are most active in rhinoceros conservation, such as those represented here, are taken into account.

\section{Acknowledgements}

This work is based on research supported in part by the National Research Foundation of South Africa (grant numbers $93446 \&$ 90694).

\section{Author contributions}

OW led the research design, fieldwork, primary data analysis, and the writing of the article. GC and DB made significant contributions to the research design, implementation, analysis and write-up of this research.

\section{References}

Bennett, E.L. (2015) Legal ivory trade in a corrupt world and its impact on African elephant populations. Conservation Biology, 29, 54-6o.

Bernard, H.R. (2002) Research Methods in Anthropology. Qualitative and Quantitative Approaches. 3rd edition. AltaMira Press, Oxford, UK.

BIGGS, D., BAN, N.C. \& HALL, C.M. (2012) Lifestyle values, resilience, and nature-based tourism's contribution to conservation on Australia's Great Barrier Reef. Environmental Conservation, 39, 370-379.

Biggs, D., Courchamp, F., Martin, R. \& Possingham, H.P. (2013) Legal trade of Africa's rhino horns. Science, 339, 1038-1039. 
Castley, J.G., Boshoff, A.F. \& Kerley, G.I.H. (2001) Compromising South Africa's natural biodiversity-inappropriate herbivore introductions. South African Journal of Science, 97, 344-348.

CHIld, B. (2012) The sustainable use approach could save South Africa's rhinos. South African Journal of Science, 108, 21-25.

CITES (2016) The CITES Appendices. Http://www.cites.org/eng/app/ index.shtml [accessed 3 October 2016].

Clough, P. (2000) Encouraging Private Biodiversity: Incentives for Biodiversity Conservation on Private Land. Report to the Treasury. New Zealand Institute of Economic Research, Wellington, New Zealand.

Collins, A., Fraser, G. \& Snowball, J. (2013a) Rhino poaching: supply and demand uncertain. Science, 340, 1167.

Collins, A., Fraser, G. \& Snowball, J. (2013b) Could a regulated market approach for rhinoceros horns work in South Africa? Some practical issues and concerns. Working paper. Rhodes University, Grahamstown, South Africa.

Cousins, J.A., SADler, J.P. \& Evans, J. (2008) Exploring the role of private wildlife ranching as a conservation tool in South Africa: stakeholder perspectives. Ecology and Society, 13(2), 43.

Crookes, D.J. \& Blignaut, J.N. (2015) Debunking the myth that a legal trade will solve the rhino horn crisis: a system dynamics model for market demand. Journal for Nature Conservation, 28, 11-18.

Cumming, G.S., Allen, C.R., BAn, N.C., Biggs, D., Biggs, H.C., Cumming, D.H.M. et al. (2015) Understanding protected area resilience: a multi-scale, social-ecological approach. Ecological Applications, 25, 299-319.

DEA (Department of Environmental Affairs) (2016) Minister Molewa highlights progress in fight against rhino poaching. Https:// www.environment.gov.za/mediarelease/molewa_highlights progress_onrhinopoaching2016 [accessed 10 May 2016].

Di Minin, E., Laitila, J., Montesino-Pouzols, F., LeaderWilliams, N., Slotow, R., Goodman, P.S. et al. (2015) Identification of policies for a sustainable legal trade in rhinoceros horn based on population projection and socioeconomic models. Conservation Biology, 29, 545-555.

Duffy, R. (2014) Waging a war to save biodiversity: the rise of militarized conservation. International Affairs, 90, 819-834.

Duffy, R., Emslie, R.H. \& Knight, M.H. (2013) Rhino Poaching: How Do We Respond? Evidence on Demand, London, UK.

Dutton, A.J., Gratwicke, B., Hepburn, C., Herrera, E.A. \& Macdonald, D.W. (2013) Tackling unsustainable wildlife trade. In Key Topics in Conservation Biology 2 (eds D.W. Macdonald \& K. J. Willis), pp. 74-91. John Wiley \& Sons, Chichester, UK.

ECPTA (Eastern Cape Parks \& Tourism Agency) (2015) Nature \& conservation. Http://www.visiteasterncape.co.za/natureconservation/ [accessed 12 March 2015].

Emslie, R.H. \& KNight, M.H. (2014) Update on African Rhino Status and Poaching Trends From IUCN SSC African Rhino Specialist Group (AfRSG). Report to CITES Standing Committee 65th meeting. Http://www.rhinoresourcecenter.com/pdf_files/140/ 1406156621.pdf [accessed 3 October 2016].

Eustace, M. (2012) Rhino poaching: what is the solution? Http://www. bdlive.co.za/articles/2012/01/20/rhino-poaching-what-is-thesolution [accessed 13 March 2015].

Ferreira, S.M., Botha, J.M. \& Emmett, M.C. (2012) Anthropogenic influences on conservation values of white rhinoceros. PLOS ONE, 7 (9), e45989.

Ferreira, S.M., Pfab, M. \& Knight, M. (2014) Management strategies to curb rhino poaching: alternative options using a costbenefit approach. South African Journal of Science, 110, 1-8.

Hamman, M. \& Tuinder, V. (2012) Introducing the Eastern Cape: A Quick Guide to its History, Diversity and Future Challenges. Stockholm Resilience Centre, Stockholm, Sweden.
Kagande, S.M. \& Musarurwa, L.K. (2014) Conserving the African rhinoceros. Biodiversity and Conservation, 23, 497-502.

Kamuti, T. (2014) The fractured state in the governance of private game farming: the case of KwaZulu-Natal Province, South Africa. Journal of Contemporary African Studies, 32, 190-206.

Kerley, G.I.H., Landman, M., Kruger, L. \& Owen-Smith, N. (2008) The effects of elephants on ecosystems and biodiversity. In Elephant Management. A Scientific Assessment for South Africa (eds R.J. Scholes \& K.G. Mennell), pp. 101-147. Wits University Press, Johannesburg, South Africa.

Langholz, J.A. \& Kerley, G.I. (2006) Combining Conservation and Development on Private Lands: An Assessment of Ecotourism-Based Private Game Reserves in the Eastern Cape. Centre for African Conservation Ecology, Port Elizabeth, South Africa.

LAURANCE, W.F. (2004) The perils of payoff: corruption as a threat to global biodiversity. Trends in Ecology \& Evolution, 19, 399-401.

Leader-Williams, N. (1992) World Trade in Rhino Horn: A Review. TRAFFIC International, Cambridge, UK.

Lee, D.E. \& Du Preez, M. (2015) Determining Visitor Preferences for Rhinoceros Conservation Management at Private, Ecotourism Game Reserves in the Eastern Cape Province, South Africa: A Choice Modeling Experiment. Working Paper No. 502 of Economic Research Southern Africa, Cape Town, South Africa.

Le Saout, S., Hoffmann, M., Shi, Y., Hughes, A., Bernard, C., Brooks, T.M. et al. (2013) Protected areas and effective biodiversity conservation. Science, 342, 803-805.

Lindsay, P. \& Taylor, A. (2011) A Study on the Dehorning of African Rhinoceroses as a Tool to Reduce the Risk of Poaching. Endangered Wildlife Trust and the South African Department of Environmental Affairs, Johannesburg, South Africa.

Maciejewski, K. \& Kerley, G.I.H. (2014) Understanding tourists' preference for mammal species in private protected areas: is there a case for extralimital species for ecotourism? PLoS ONE, 9(2), e88192.

Martin, R.B. (2012) A Legal Trade in Rhino Horn: Hobson's Choice. Rhino Survival Trust, Johannesburg, South Africa.

Milliken, T. \& Shaw, J. (2012) The South Africa-Viet Nam Rhino Horn Trade Nexus: A Deadly Combination of Institutional Lapses, Corrupt Wildlife Industry Professionals and Asian Crime Syndicates. TRAFFIC, Johannesburg, South Africa.

Newing, H. (2010) Conducting Research in Conservation: Social Science Methods and Practice. Routledge, London, UK.

Ngwakwe, C.C. \& Mokgalong, N.M. (2014) Consumer income growth and rhino poaching in South Africa. Environmental Economics, 5, 42-52.

Pernetta, A.P. (2014) A disappearing drylands icon? White rhinoceros conservation and the need for public-private partnerships. Biodiversity, 15, 231-233.

Rademeyer, J. (2012) Killing for Profit: Exposing the Illegal Rhino Horn Trade. Random House Struik, Cape Town, South Africa.

RHODES UNIVERSITY (2014) Ethical Standards for Research on Human and Animal Subjects: Rhodes University Ethical Standards Committee Handbook. Http://www.ru.ac.za/media/rhodesuniversity/content/ ethics/RUESC_Handbook_\%202014-11-21_v\%201.01.pdf [accessed 11 April 2015].

Ripple, W.J., Newsome, T.M., Wolf, C., Dirzo, R., Everatt, K.T., Galetti, M. et al. (2015) Collapse of the world's largest herbivores. Science Advances, 1(4), e1400103.

Rutherford, M.C., Powrie, L.W. \& Husted, L.B. (2014) Herbivoredriven land degradation: consequences for plant diversity and soil in arid subtropical thicket in south-eastern Africa. Land Degradation \& Development, 25, 541-553.

Sims-Castley, R., Kerley, G.I.H., Geach, B. \& Langholz, J. (2005) Socio-economic significance of eco-tourism based private game 
reserves in South Africa's Eastern Cape Province. Parks: Protected Areas Programme. Private Protected Areas, 15, 6-18.

SKEAD, C.J. (1987) Historical Mammal Incidence in the Cape Province, Vol. 2: The Eastern Half of the Cape Province, Including the Ciskei, Transkei and East Griqualand. Chief Directorate of Nature and Environmental Conservation, Cape Town, South Africa.

Smith, N. \& Wilson, S.L. (2002) Changing Land Use Trends in the Thicket Biome: Pastoralism to Game Farming. Terrestrial Ecology Research Unit, University of Port Elizabeth, Port Elizabeth, South Africa.

Smith, R.J., Biggs, D., St John, F.A.V., 'T SAs-Rolfes, M. \& BARrington, R. (2015) Elephant conservation and corruption beyond the ivory trade. Conservation Biology, 29, 953-956.

Smith, R.J., Muir, R.D.J., Walpole, M.J., Balmford, A. \& LeaderWilliams, N. (2003) Governance and the loss of biodiversity. Nature, 426, 67-70.

Smith, R.J., Roberts, D.L., Duffy, R. \& St John, F.A.V. (2013) New rhino conservation project in South Africa to understand landowner decision-making. Oryx, 47, 323.

SNIJDERS, D. (2014) Wildlife policy matters: inclusion and exclusion by means of organisational and discursive boundaries. Journal of Contemporary African Studies, 32, 173-189.

Taylor-Powell, E. \& Renner, M. (2003) Analyzing Qualitative Data. University of Wisconsin, Cooperative Extension, Madison, USA.
Tномаs, D.R. (2006) A general inductive approach for analyzing qualitative evaluation data. American Journal of Evaluation, 27, 237-246.

WESSA (The Wildlife and Environment Society of South AFRICA) (2015) Current rhino poaching stats. Http://wessa.org.za/ get-involved/rhino-initiative/current-rhino-poaching-stats.htm [accessed 12 March 2015].

Wilson, G. (2016) 19th rhino killed in East Cape. Http://www. heraldlive.co.za/news/2016/10/12/19th-rhino-killed-east-cape/ [accessed 23 October 2016].

WWF (2015) Make or break year for South Africa's rhinos after poaching hits record high. Http://wwf.panda.org/wwf_news/? 237450/Make-or-break-year-for-South-Africas-rhinos-afterpoaching-hits-record-high [accessed 12 March 2015].

\section{Biographical sketches}

At the time of writing OLIVER WRIGHT was a post-graduate student in the Department of Environmental Science at Rhodes University, South Africa. He is now a conservation practitioner working in the private sector in South Africa. Georgina Cundill has worked on issues of environmental governance, social justice and natural resource management in South Africa and Chile. DU AN BIGGs has worked on a wide range of conservation issues, including illegal wildlife trade and community-based conservation. 